\title{
Determinants of Marketing Performance on Durian Product for Exporting: Study in South of Thailand
}

\author{
Waleerak Sittisom ${ }^{1}$, Paristha Thanomvech ${ }^{2}$, Witthaya Mekhum ${ }^{1} \&$ Napasri Suwanajote ${ }^{1}$ \\ ${ }^{1}$ Suan Sunandha Rajabhat University, Bangkok, Thailand \\ ${ }^{2}$ Faculty of Business Administration, Thonburi University, Bangkok, Thailand \\ Correspondence: Waleerak Sittisom, Suan Sunandha Rajabhat University, Bangkok, Thailand. E-mail: \\ waleerak.si@ssru.ac.th \\ Received: July 17, 2020 \\ Accepted: September 4, 2020 \\ Online Published: October 8, 2020 \\ doi:10.5430/rwe.v11n6p164 \\ URL: https://doi.org/10.5430/rwe.v11n6p164
}

\begin{abstract}
Thailand is the major exporter of durian products worldwide. Durian is the most important fruit and it's called the king of fruits in Thailand. The economy of Thailand majorly bases on the exporting of durian to other related countries. The major objective of this study to find out the determinants of marketing performance that affect the durian product exporting in the south of Thailand. Respondents of this study are employees working in exporting companies working in the south of Thailand. Data is collected through a drop-down survey method and a questionnaire is used. After it, Smart PLS used for analysis. Results revealed that determinants of marketing performance like (Product capability, Promotion, and Distribution capability) have a positive, significant impact on exporting of durian. Two mediators including attitude towards exporting have a positive effect but the second motivation to export has no effect on durian export. Attitude towards exporting mediates the relationship between distribution capability and exporting of durian. Motivation to export has no mediation between promotion capability and export of durian. The study recommends to exporters that for increasing export to other countries they should focus on marketing performance determinants.
\end{abstract}

Keywords: promotion capability, product capability, distribution capability, attitude towards exporting, motivation to export

\section{Introduction}

A country's long-term success depends on the productivity of that country. The productivity of any state depends on their yield production in different sectors with the help of human, capital, and natural resources used in nations' yield production. The objective of the country behind this productivity is to maintain the standard of living of their people, also to support the sustainable growth of the economy and also earn revenue by export the production of different sectors. Like other important sectors, fruit production in many states is quite fixed from many past years and the global export of fruit is increasing day by day (Karahoca, Karahoca, \& Aksöz, 2018). The demand for fresh fruit increase gradually because it tends to a healthier lifestyle and people also pay a higher amount of money for buying the out seasoned fruit that export from other states.

Thailand is called the kitchen of the world because Thailand has a landscape that is very helpful for growing any type of fruits, vegetables, and agrarian products. Thailand produces main types of agrarian products and also export it to many other countries, a product like for human needs, animal feeds, and other related products. The most important agricultural products exported were rubber (USD 4,413 million) followed by rice (USD 4,382 million), cassava (USD 2,925 million), processed chicken (USD 2,026 million), and fruits (USD 1,544 million). Thai fruits include Durian, Longan, Mangosteen, Lychee, and Rambutan. Major importer partners of Thailand are the Republic of China, Hong Kong, Indonesia, and Taiwan (Hanfan \& Setiawan, 2018). 


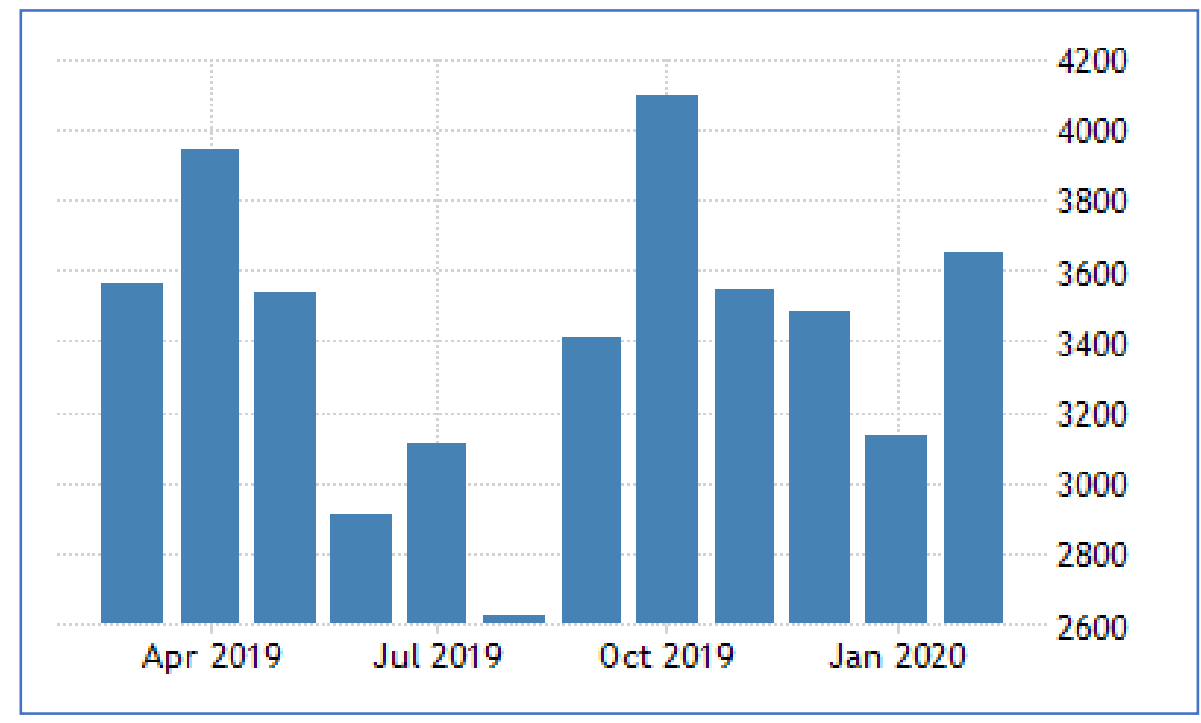

Figure 1. Export industry outlook (2019)

Source: Various reports for the year 2019

No doubt, Thailand is a major and big exporter of durian product but the important competitors of Thailand are Vietnam and Cambodia. These two countries also producing fresh ripe durian fruit and also export it. In the future, it is expected that these two countries replace the place of Thailand from the number one exporter. Because Thailand has some problems related to exporting the durian. There are still some toxic and biological issues, early maturity while cutting and some related problems to the marketing performance determinants in exporting (Obeng \& Mkhize, 2017). Figure 1 shows the fluctuating in the export of durian product from Thailand and it has above discussed underlying reasons.

The literature is evident that exporting companies' performance largely depends on the marketing performance detriments like (promotion capabilities, product capabilities, and distribution capabilities). Prior studies argued that promotion of a product that exported in those countries who export them has a positive impact on increasing the export. This distribution of exporting products also has a positive impact on increasing export to other countries. Like all these other related variables, the product also means the quality of products has a major effect on exporting the product. Good quality products increase the export otherwise decrease in exports (Fan, Hossain, Islam, \& Yahia, 2019; Girangwa, Rono, \& Mose, 2020; Göral, 2020; Gu \& Prah, 2020; Papadas, Avlonitis, \& Carrigan, 2017). Figure 2 showed that the theoretical link between the marketing performance determinants and durian product exporting with the mediation of motivation to export and Attitude towards exporting.

This study wants to analyze the impact of determinates of marketing performance like (promotion capabilities, product capabilities, and distribution capabilities) on durian product exporting with the mediation of motivation to export and attitude toward exporting among employees working in exporting companies of south of Thailand. This study has a theoretical contribution in previous literature. As previous literature argued that limited studies were conducted on analyzing the impact of marketing performance determinants on exporting a product but it all missing the exporting of durian product. Various other studies were conducted on exporting of durian product but missing the impact of determinants of marketing performance (Zhao \& Priporas, 2017).

The practical implication of this study is, as this study recommended the exporters to increase the export by focusing on the determinants of marketing performance like (promotion capabilities, product capabilities, and distribution capabilities) on durian product exporting.

\section{Literature Review}

For many decades Thailand is the best and largest exporter of durian fruit. In the last few decades, it has increased its export capacity to many times. Thailand used to import around 300 shipping containers full of durian every year, but now import more than 1500 containers per year. In the current year, 2020 export of durian has effected due to COVID-19, and now Thailand is focusing on its local fruit market (Alrubaiee, Aladwan, Joma, Idris, \& Khater, 2017). 
This research aimed to analyze the marketing performance determinants of durian fruit export from Thailand o China. Capabilities of the durian fruit, promotion of fruit, and distribution are taken as determinants of performance. The business of exporting fruit in Thailand is from small-medium to large enterprises. This model shows marketing determinants have an important role in the export of durian fruit. Product capability may have influencing to increase marketing performance of durian. Thailand is the largest importer of durian; its volume of durian has soared in the last 5 years. This fruit has its maximum export in the Chinese Market (Camilleri \& Camilleri, 2017). This research can conclude how determinants are influencing the export of this product.

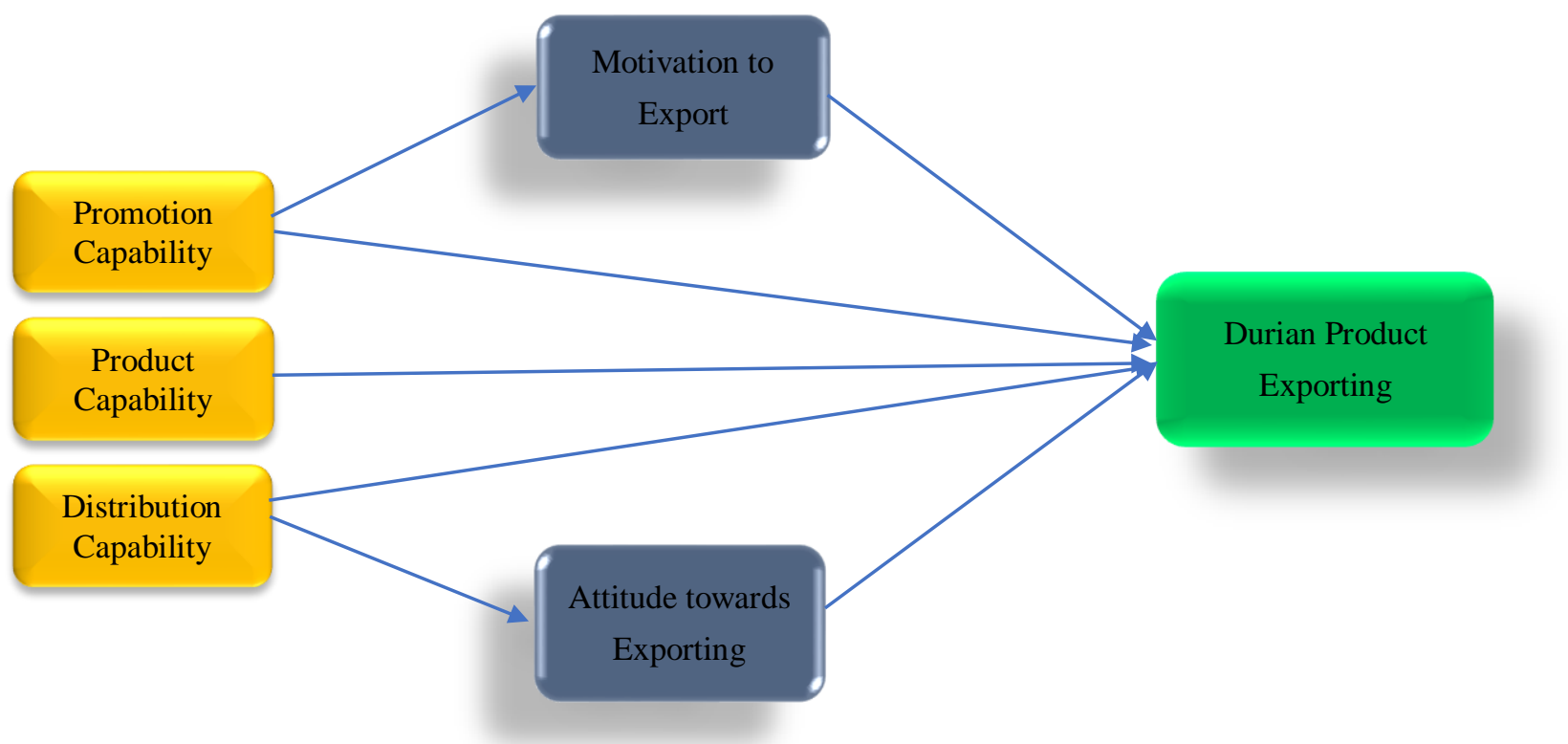

Figure 2. The theoretical framework of the study shows the relationship between marketing performance determinants and exporting of durian product

\subsection{Promotion Capability, Motivation to Export and Durian Product Exporting}

The company's strategy to enter the emerging market has become a front-line objective for each company. All marketing strategies affect the performance of each company and product. The performance of the company or product depends on the different internal and external factors. Marketing determinants also have a role in product performance. On the base of these capabilities, products become popular in different markets. Determinates of marketing performance like promotion capabilities of a product also affect the popularity of a product. Promotion capability is the product's ability that how and how much it is possible to do its promotion. This promotion strategy has an effect on performance (Hur, Lee, \& Choo, 2017). Durian fruit is exported from Thailand to China in a large quantity. Here the objective of the research is to analyze the effect of promotion capability of durian fruit on its export to the Chinese market.

Further, that market entry strategy is dependent on the promotion capabilities of the product and companies as well. For different products and companies, these capabilities differ from product to product. The promotion of durian in the Chinese market can increase the demand for this fruit. Thailand is one developing the promotional capabilities because Malaysia is now allowed in the Chinese market to sell its durian which can be a competitor to Thailand's durian (Bassiri-Jahromi, 2018). How to export can be increased, either the promotion capability of durian could be a tool, form the discussed literature hypothesis can be formulated given as:

H1: Promotion capability has a positive significant impact on Durian product exporting

As the quality of the product increases the confidence of the sales force increases about the product. Internal characteristics and market demand for products derive the popularity of the particular product. When a product is doing well in the market and giving earnings to the seller, the motivation of the seller increases to the sale of that product. Motivation to sell a product in the foreign market is the motivation to export a product to other countries. Durian is a fruit that is particularly exported to China with good quality. According to the Thailand traders of durian, they sell A 
and $\mathrm{AB}$ quality in the foreign markets and others in the local markets (Biswas et al., 2017). Quality of the fruit is the promotion of fruit that increases the motivation for traders to export.

Market orientation is regarded as an important factor in determining the development of the market sensing capability. There is an effect of market factors on the performance of sales. Marketing determinants extract the market forces toward a product. A good promotion capability product becomes popular for a customer and for a trader as well. Durian of Thailand is especial for its size and smell. It has the longest period of cultivation from March to December and exported fresh to the Chinese markets. Promotion capabilities if durian is effective for trade and attractive for traders. These capabilities give the confidence to export (DeCesare, 2018). As some studies have concluded that motivation for trading is positively related to the safety of the product to generate profits. So from the discussion, we can assume that the promotion capabilities of the durian of Thailand that are its quality and strategies can motivate the traders to export its Chinese market. To verify the assumed results we formulate a hypothesis given as:

H2: Promotion capability has a positive significant impact on motivation to export

There are several possible effects of the promotion capabilities that should be owned by companies to increase their marketing performance for different markets. One is promotion capability and the other is motivation to export. Promotion capability could be the internal capability of the product or of the company. But the motivation to export is the external capability. Motivation to export means for a product there should be a number of people willing to trade it in the foreign markets for benefits and they ensure that people will buy their product and they will get the benefit. Motivation is the key to the success of any business (Guo et al., 2017). Well-motivated companies and salesforces generate a positive impact on the performance of the product.

Performance determinants will lead the company to have better innovative strategies for performance compared to competitors. Motivation to trade the products will cause the products to enhance their export. For durian trade in the Chinese market, the study will find the effects of motivation to export durian on the export quantity of durian fruit. Besides the capability to promote, motivation is also required. In the current era of highly competitive business, a company's business success depends on its capability to predict market opportunities and to carefully see the organization's resources in capturing any opportunities (Jiang et al., 2017). Thailand is using its resources of motivation to increase the export for durian product, to determine the effects of motivation to export a testing hypothesis can be developed as

H3: Motivation to export has a positive significant impact on Durian product exporting

According to customs data, Exports of Thailand that were only for fruits and nuts were more than $\$ 255$ million worth to China in the first two months of this year - a staggering $23.1 \%$ decrease relative to last year. This decrease in export due to the current pandemic that is demotivating to fruit trader in Thailand. The promotion of durian is due to its strategies and capability to satisfy customer demands. It was increasing day by day by improving promotion strategies. Not for no reason are Thai durians considered the world's best (Kim et al., 2018). Fruits are harvested when ripped at $70-80 \%$, thus allowing them to fully ripen during their long journey toward other countries.

Thai fruit market has an immense increase in the volume of export from the last few decades. It due to the performance of marketing determinants used in the export of the fruit. According to Ben 2017 promotion capabilities increase the demand for a product in each market of its trade. In another research, it was found, a positive relation for promotion capability and export of products of cosmetic research in China. Motivation also has the role of export and promotion of a product. In the previous discussion, it was found that a positive relation of motivation for both variables. So now from the literature, it also can be concluded that motivation can play the role of the mediator where durian is exported to China has the relation with promotion capability (Lau \& Bruno, 2018). To test this mediation relation hypothesis can be formulated as:

H4: Motivation to export mediates the relationship between promotion capability and durian product exporting.

\subsection{Product Capability and Durian Product Exporting}

Product capability is the internal property of the product. It means the characteristics and properties of the product that fulfill the needs of the customer. It can be described as how a product satisfies the needs. Products are different in their characteristics and specification. They are required by the customers for their special attraction. If a product has that much attraction due to its specialty then it also has great demand from the salesperson as well. A person who seeks benefit and high demand cannot trade a product with low product capability. As product capability increases its trading in the local market and as well as in the foreign market increases (Naureen et al., 2017). Durian is having unique properties in the Chinese market. It is special due to its unique smell and fresh quality. Malaysia is entering the Chinese 
market to export its durian but it has to face very low competition because it is exporting refrigerated durian which is different in taste as well.

As of Robin 2014 when a product has a good image in the market it can increase its sales by applying the product capability. Here the objective of the research is to find out the relation which can describe the determinants of marketing performance. As performance or capability goes up the export of the product may also be influenced (Handika \& Ekananda, 2019; Seppälä, Hankonen, Korkiakangas, Ruusuvuori, \& Laitinen, 2018). The durian that is of quality from Thailand may also have an impact to export in large quantities. To test this assumption, we formulate a hypothesis as:

H5: Product capability has a positive significant impact on Durian product exporting

\subsection{Distribution Capability, Attitude Towards Exporting and Durian Product Capability}

Distribution capability is the capacity to deliver the product or services to the market or end-user. Distribution capacity plays an important role in the success and development of any organization. A strong supply chain capability is a sign of success. It allows products to get access to efficient markets. The timely distribution of products makes it possible to satisfy the customer. Competitive pressures in domestic markets, as well as the globalization of economic activities, have encouraged many firms to seek new opportunities. It is necessary to have a place in the new markets. Global business has many opportunities to export products from country to country. Now it has become easier to export. Many studies have been conducted on the export trade of products and services. No study has particularly has examined the attitudes, and capabilities that propel some products to embark on an internationalization path (Wang et al., 2017).

The competition around the world continues to intensify, firms are seeking strategies that will increase export performance. There are many factors that affect the performance of export positively and negatively as well. Distribution is also one of the keys. According to Je Sin Le 2017 in his work on export, it was mentioned that for export a product distribution capability of product is important. In many other similar studies supply chain has been described as the key to export. In Thailand for exporting durian to China, distribution capability for durian has been made effective. This capability may have positive effects on its exports (Bai, Jiang, Li, Chen, \& Li, 2018; He, 2019). To analyze the effects of distribution capability of durian formulated hypothesis is given as:

H6: Distribution capability has a positive significant impact on Durian product exporting

Since the 1960s a substantial literature has focused on the export behavior of firms in the manufacturing sector. Export and imports of the manufacturing sector relevant to the different aspects. A study by Paul G. Patterson has worked in the perception regarding a service firm's attitude toward exporting. The trend toward globalization of the world markets underscores the importance of understanding firm behavior and performance in export markets. The main focus of the export research is on internal and external determinants. In Thailand's export of manufacturing, a product is less than the natural items. From their natural exports fruit market is large enough and well developed.

Export marketing is examined on the performance of the export. The attitude of the firm also considerable export performance. Positive attitude toward exporting increase export performance. In a similar way, a good distribution capability of a product can affect the attitude of the seller. It is evident from the researches that attitude is a way of thinking and feeling of a person about something. A positive attitude is positive thinking about something. It also applies to product buying or selling decisions. The attitude becomes positive due to the services and product capabilities that can make the seller and buyer more satisfied. A positive attitude increases the attraction for the product and makes the decision of the respondent easy (Bai et al., 2018). Distribution capability is the supporting factor that builds the capability of the product. It makes a good perception of the seller. For durian fruit to find the relation of distribution capability hypothesis can be formulated as:

H7: Distribution capability has a positive significant impact on attitude towards exporting.

Product exporting is dependent on the supply of the product as distribution capabilities and its demand with special characteristics of unique selling. The exports of any country count significantly in the GDP of the country. Many researches have been conducted in this regard. When exporting goods or services there are many things to consider. Export is not only about the product it depends on the chain of action taken from producing the product to selling them in the market. This procedure consists of marketing activities. Improved marketing performance and supply chain can bring a significant change in export. Attitude toward exporting also counts toward the export of a product.

A positive attitude can improve exporting as it ensures a trader to build capacity and confidence. In a study by Richard ben 2011, he has explained that attitude can examine when a seller or motivated to sell the products. In Thailand, durian fruit has the quality and its place in the market so traders of export are getting the confidence to export. Their attitude 
toward exporting is improving. The Thai government is helping exporters to be efficient ( $\mathrm{Li}, \mathrm{He}, \mathrm{Li}, \& \mathrm{Li}, 2018)$. Many researchers have found the reason for Thailand's increasing export of durian. The attitude of the exporter can also be considered. To examine this relation of an attitude of exporting with durian export a testing hypothesis is constructed as:

H8: Attitude towards exporting has a positive significant impact on Durian product exporting.

As discussed in the above paragraph literature was found related to the relation of distribution capability and durian product exporting. Literature also has shown that attitude toward exporting can also affect the distribution capability and product exporting as well. Many researches have concluded that these describe variables are connected positively. These factors improve exporting when working positively. Global export markets are now working on new factors that can help them to increase exporting efficiency. Most of the researches have addressed the variable directly affecting factors on export. This study will cover the gap of mediation of attitude between distribution capability and product exporting (Ho, Ng, Vivi, Ng, \& Susela, 2020; Rodrigues, Zhang, Jiang, Aeloiza, \& Cairoli, 2018). A survey report of Thailand fruit market has examined the attitudes of traders to export the durian fruit, local traders of the market have given their positive feedback and a year later they were asked the same question, it was observed that $8 \%$ of the respondents with a positive attitude that was local traders were exporting their fruits to the foreign markets. Existing exporters with positive feedback and satisfied with the capabilities were now sending more to the foreign markets. A study of south Asia for their Agri products has also given similar results for a positive attitude and exporting. It is now considered that relation of distribution capability that makes the positive attitude of exporting can be mediated with the attitude of exporting.

Thai fruit is having good capabilities of distribution and exporting history toward China. It has good demand in the market and being exported for many years. Exporting attitude is regular positive. In the current year, it is effective due to the pandemic of COVID-19 (Sheng \& Wang, 2018). The study may give biases in results due to the abnormal trading conditions. To find the mediation of attitude for export of durian to China hypothesis is formulated given as:

H9: Attitude towards exporting mediates the relationship between distribution capability and durian product exporting.

\section{Research Methodology}

The methodology section of every research is an important step. In this section, the authors describe the research approach, population, and respondents of the study also tell about their process and techniques of determining sample size, data calculation and sample with the process of data collection. This study used a quantitative research design instead of qualitative and mixed research methods. In quantitative research, design formulated hypotheses are tested by calculating and analyzing the data.

The purpose of conducting this research is to find out the impact of determinants of marketing performance on exporting durian product with the mediation of attitude towards motivation and motivation towards exporting. Participants of this study were employees working in exporting companies in the south of Thailand. 300 sample size was good and it is proven from Comrey and Lee (1992), this size is satisfactory for analyzing the variables. The sample is determined by the snowball sampling method. In the snowball sampling method, respondents give the questionnaire to their known workers working in the same sector. This method is a quick and efficient data collection. The questionnaire includes respondents' demographic information related questions and also the question related to variables like (Product capabilities, promotion capabilities, distribution capabilities, exporting durian product, motivation towards exporting, and attitude towards exporting). These all related questions adopted from previous studies. These questionnaires administrated in a 7-point Likert scale design.

After finalizing the questionnaire author drop the questionnaire at respondents' place and tell them the purpose behind data collection and also ensure them that their information not disclosed to anyone and use only for research purpose. After five days respondents brought back all the filled questionnaires from respondents and acknowledged the respondents. After the collection of data, Smart PLS was used for analyzing the data.

\section{Data Analysis}

Below given Table 1, showing the data statistics. It includes missing values statistics, mean median, and standard deviation of data. 
Table 1. Data statistics

\begin{tabular}{|c|c|c|c|c|c|c|c|c|c|}
\hline & No. & Missing & Mean & Median & Min & Max & SD & Kurtosis & Skewness \\
\hline $\mathrm{PC} 1$ & 1 & 0 & 3.6 & 4 & 1 & 5 & 1.097 & -0.373 & -0.515 \\
\hline $\mathrm{PC} 2$ & 2 & 0 & 3.523 & 4 & 1 & 5 & 1.156 & -0.712 & -0.418 \\
\hline PC3 & 3 & 0 & 3.508 & 4 & 1 & 5 & 1.401 & -1.058 & -0.552 \\
\hline PC4 & 4 & 0 & 3.472 & 4 & 1 & 5 & 1.462 & -1.184 & -0.5 \\
\hline PRC1 & 5 & 0 & 3.379 & 4 & 1 & 5 & 1.471 & -1.173 & -0.541 \\
\hline $\mathrm{PRC} 2$ & 6 & 0 & 3.497 & 4 & 1 & 5 & 1.147 & -0.707 & -0.384 \\
\hline PRC3 & 7 & 0 & 3.487 & 4 & 1 & 5 & 1.221 & -0.809 & -0.421 \\
\hline PRC4 & 8 & 0 & 3.492 & 4 & 1 & 5 & 1.39 & -1.04 & -0.538 \\
\hline DC1 & 9 & 0 & 3.451 & 4 & 1 & 5 & 1.429 & -1.128 & -0.512 \\
\hline DC2 & 10 & 0 & 3.554 & 4 & 1 & 5 & 1.077 & -0.333 & -0.476 \\
\hline DC3 & 11 & 0 & 3.538 & 4 & 1 & 5 & 1.156 & -0.685 & -0.456 \\
\hline DC4 & 12 & 0 & 3.359 & 4 & 1 & 5 & 1.48 & -1.208 & -0.502 \\
\hline ME1 & 13 & 0 & 3.605 & 4 & 1 & 5 & 1.092 & -0.327 & -0.545 \\
\hline ME2 & 14 & 0 & 3.528 & 4 & 1 & 5 & 1.156 & -0.703 & -0.43 \\
\hline ME3 & 15 & 0 & 3.251 & 4 & 1 & 5 & 1.294 & -0.951 & -0.406 \\
\hline ME4 & 16 & 0 & 3.236 & 3 & 1 & 5 & 1.279 & -0.993 & -0.332 \\
\hline $\mathrm{AE} 1$ & 17 & 0 & 3.179 & 3 & 1 & 5 & 1.278 & -1.012 & -0.296 \\
\hline $\mathrm{AE} 2$ & 18 & 0 & 3.297 & 4 & 1 & 5 & 1.337 & -1.076 & -0.325 \\
\hline AE3 & 19 & 0 & 3.328 & 3 & 1 & 5 & 1.23 & -0.785 & -0.348 \\
\hline AE4 & 20 & 0 & 3.415 & 4 & 1 & 5 & 1.14 & -0.663 & -0.407 \\
\hline DPE1 & 21 & 0 & 3.549 & 4 & 1 & 5 & 1.355 & -0.92 & -0.583 \\
\hline DPE2 & 22 & 0 & 3.446 & 4 & 1 & 5 & 1.257 & -0.697 & -0.548 \\
\hline DPE3 & 23 & 0 & 3.426 & 4 & 1 & 5 & 1.347 & -1.06 & -0.367 \\
\hline DPE4 & 24 & 0 & 3.39 & 4 & 1 & 6 & 1.186 & -0.664 & -0.348 \\
\hline DPE5 & 25 & 0 & 3.421 & 3 & 1 & 5 & 1.197 & -0.947 & -0.244 \\
\hline DPE6 & 26 & 0 & 3.477 & 4 & 1 & 6 & 1.274 & -0.843 & -0.233 \\
\hline
\end{tabular}

PC: Product capability, PRC: Promotion capability, DC: Distribution capability, AE: Attitude towards exporting, ME: Motivation to export, DPE: Durian product exporting

Smart PLS has two steps. In one step reliability and validity are examined and it is called measurement model assessment. Second is a structural model assessment in which the formulated hypothesis analyzed. In the first step, the measurement model of PLS was carried out and it generate Figure 3 and below-given Table 2, 3, and Table 4. Table 2 and Table 3 showed the values of the factor loading, Alpha, composite reliability, and average variance extracted respectively (Hair, Hollingsworth, Randolph, \& Chong, 2017). These values used for analyzing the reliability of data. Next Table 4 showed the value of validity by using the HTMT. All given values of Reliability and validity are under accepted range. 


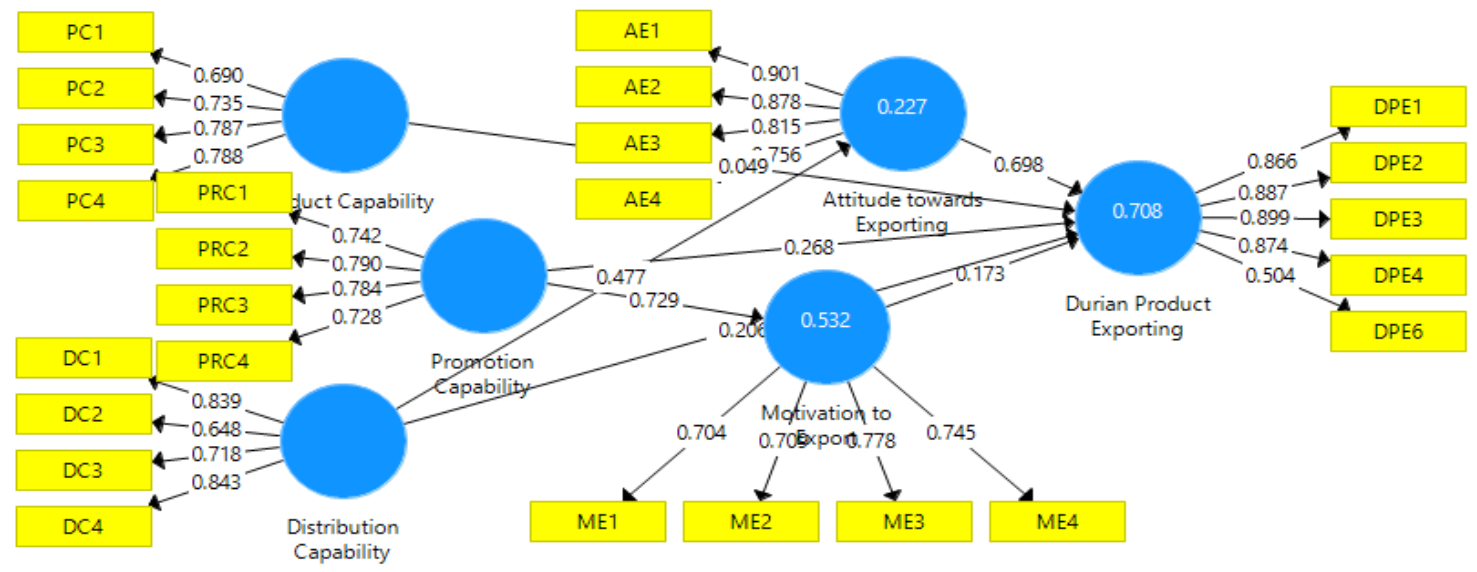

Figure 3. Measurement model

Table 2. Factor loadings

\begin{tabular}{|c|c|c|c|c|c|c|}
\hline & $\begin{array}{c}\text { Attitude } \\
\text { towards } \\
\text { Exporting } \\
\end{array}$ & $\begin{array}{c}\text { Distribution } \\
\text { Capability } \\
\end{array}$ & $\begin{array}{c}\text { Durian } \\
\text { Product } \\
\text { Exporting } \\
\end{array}$ & $\begin{array}{c}\text { Motivation } \\
\text { to Export }\end{array}$ & $\begin{array}{c}\text { Product } \\
\text { Capability }\end{array}$ & $\begin{array}{l}\text { Promotion } \\
\text { Capability } \\
\end{array}$ \\
\hline $\mathrm{AE} 1$ & 0.901 & & & & & \\
\hline AE2 & 0.878 & & & & & \\
\hline AE3 & 0.815 & & & & & \\
\hline AE4 & 0.756 & & & & & \\
\hline DC1 & & 0.839 & & & & \\
\hline DC2 & & 0.648 & & & & \\
\hline DC3 & & 0.718 & & & & \\
\hline DC4 & & 0.843 & & & & \\
\hline DPE1 & & & 0.866 & & & \\
\hline DPE2 & & & 0.887 & & & \\
\hline DPE3 & & & 0.899 & & & \\
\hline DPE4 & & & 0.874 & & & \\
\hline DPE6 & & & 0.504 & & & \\
\hline ME1 & & & & 0.704 & & \\
\hline ME2 & & & & 0.709 & & \\
\hline ME3 & & & & 0.778 & & \\
\hline ME4 & & & & 0.745 & & \\
\hline $\mathrm{PC} 1$ & & & & & 0.69 & \\
\hline PC2 & & & & & 0.735 & \\
\hline PC3 & & & & & 0.787 & \\
\hline PC4 & & & & & 0.788 & \\
\hline PRC1 & & & & & & 0.742 \\
\hline PRC2 & & & & & & 0.79 \\
\hline PRC3 & & & & & & 0.784 \\
\hline PRC4 & & & & & & 0.728 \\
\hline
\end{tabular}

PC: Product capability, PRC: Promotion capability, DC: Distribution capability, AE: Attitude towards exporting, ME: Motivation to export, DPE: Durian product exporting 
Table 3. Measurement model results

\begin{tabular}{lcccc}
\hline & $\begin{array}{c}\text { Cronbach's } \\
\text { Alpha }\end{array}$ & rho_A & $\begin{array}{c}\text { Composite } \\
\text { Reliability }\end{array}$ & AVE \\
\hline Attitude towards Exporting & 0.858 & 0.861 & 0.905 & 0.704 \\
Distribution Capability & 0.766 & 0.788 & 0.849 & 0.588 \\
Durian Product Exporting & 0.869 & 0.903 & 0.908 & 0.672 \\
Motivation to Export & 0.715 & 0.717 & 0.824 & 0.54 \\
Product Capability & 0.743 & 0.745 & 0.838 & 0.565 \\
Promotion Capability & 0.763 & 0.771 & 0.846 & 0.58 \\
\hline
\end{tabular}

PC: Product capability, PRC: Promotion capability, DC: Distribution capability, AE: Attitude towards exporting, ME: Motivation to export, DPE: Durian product exporting

Table 4. HTMT

\begin{tabular}{lcccccc}
\hline & $\begin{array}{c}\text { Attitude } \\
\text { towards } \\
\text { Exporting }\end{array}$ & $\begin{array}{c}\text { Distribution } \\
\text { Capability }\end{array}$ & $\begin{array}{c}\text { Durian } \\
\text { Product } \\
\text { Exporting }\end{array}$ & $\begin{array}{c}\text { Motivation } \\
\text { to Export }\end{array}$ & $\begin{array}{c}\text { Product } \\
\text { Capability }\end{array}$ & $\begin{array}{c}\text { Promotion } \\
\text { Capability }\end{array}$ \\
\hline $\begin{array}{l}\text { Attitude towards Exporting } \\
\text { Distribution }\end{array}$ & & & & & \\
$\begin{array}{l}\text { Capability } \\
\text { Durian Product }\end{array}$ & 0.574 & & & & \\
Exporting & 0.738 & 0.569 & & & \\
Motivation to Export & 0.711 & 0.602 & 0.885 & & \\
Product Capability & 0.584 & 0.264 & 0.588 & 0.529 & & \\
Promotion Capability & 0.571 & 0.214 & 0.609 & 0.668 & $\ldots 634$ & \\
\hline
\end{tabular}

PC: Product capability, PRC: Promotion capability, DC: Distribution capability, AE: Attitude towards exporting, ME: Motivation to export, DPE: Durian product exporting

Next is the structural model assessment that showed the link between variables and used for analyzing the formulating hypothesis. The structural model assessment showed in Figure 4 (Albassami, Hameed, Naveed, \& Moshfegyan, 2019; Naveed, Hameed, Albassami, \& Moshfegyan, 2019). Likewise, Table 5 showed the direct effect of variables by analyzing the t-value and beta values. All hypotheses of direct link accepted rather than $\mathrm{H} 3$ because its $t$ value is below then 1.96 . So, this hypothesis is rejected.

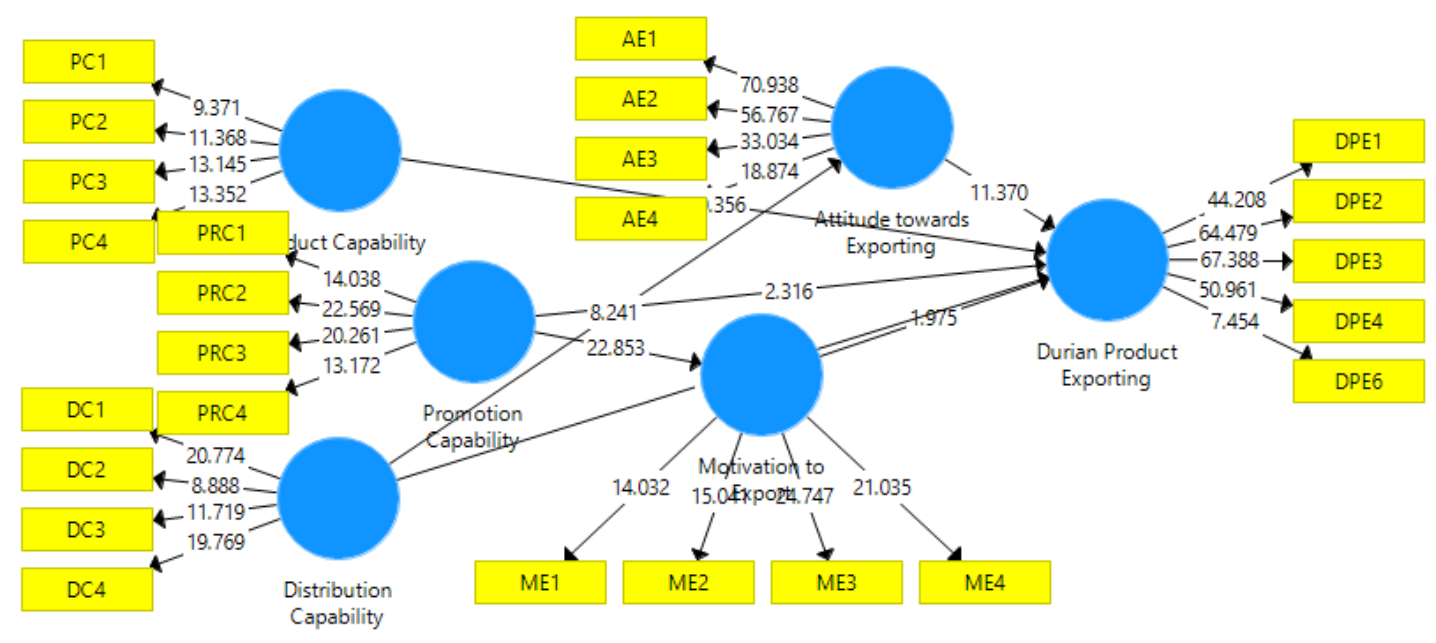

Figure 4. Structural model 
Table 5. Direct effect

\begin{tabular}{|c|c|c|c|c|c|}
\hline & $\begin{array}{c}\text { Original } \\
\text { Sample }(\mathbf{O}) \\
\end{array}$ & $\begin{array}{c}\text { Sample } \\
\text { Mean (M) }\end{array}$ & $\begin{array}{l}\text { Standard } \\
\text { Deviation } \\
\text { (STDEV) } \\
\end{array}$ & $\begin{array}{c}\text { T Statistics } \\
(|\mathrm{O} / \mathrm{STDEV}|) \\
\end{array}$ & P Values \\
\hline Attitude towards Exporting -> Durian & & & & & \\
\hline Product Exporting & 0.698 & 0.695 & 0.061 & 11.37 & 0 \\
\hline $\begin{array}{l}\text { Distribution Capability -> Attitude } \\
\text { towards Exporting }\end{array}$ & 0.477 & 0.481 & 0.058 & 8.241 & 0 \\
\hline Distribution Capability -> Durian & & & & & \\
\hline $\begin{array}{l}\text { Product Exporting } \\
\text { Motivation to Export -> Durian Product }\end{array}$ & 0.206 & 0.217 & 0.03 & 6.85 & 0 \\
\hline $\begin{array}{l}\text { Exporting } \\
\text { Product Capability -> Durian Product }\end{array}$ & 0.173 & 0.178 & 0.087 & 1.975 & 0.049 \\
\hline $\begin{array}{l}\text { Exporting } \\
\text { Promotion Capability -> Durian Product }\end{array}$ & 0.049 & 0.032 & 0.021 & 2.356 & 0.02 \\
\hline $\begin{array}{l}\text { Exporting } \\
\text { Promotion Capability -> Motivation to }\end{array}$ & 0.268 & 0.26 & 0.116 & 2.316 & 0.021 \\
\hline Export & 0.729 & 0.733 & 0.032 & 22.853 & 0 \\
\hline
\end{tabular}

PC: Product capability, PRC: Promotion capability, DC: Distribution capability, AE: Attitude towards exporting, ME: Motivation to export, DPE: Durian product exporting

After the direct effect, an in-direct effect also showed in Figure 4. Table 6 also showed the indirect effect (mediation) of attitude towards exporting and motivation to export. By seeing the $t$ values, it is revealed that mediation of motivation to export is rejected but mediation of attitude towards exporting is accepted and graphs showed in Figure 5.

Table 6. Indirect effect

\begin{tabular}{lccccc}
\hline & $\begin{array}{c}\text { Original } \\
\text { Sample } \\
(\mathbf{O})\end{array}$ & $\begin{array}{c}\text { Sample } \\
\text { Mean } \\
(\mathbf{M})\end{array}$ & $\begin{array}{c}\text { Standard } \\
\text { Deviation } \\
(\text { STDEV })\end{array}$ & $\begin{array}{c}\text { T Statistics } \\
([\mathbf{O} / \text { STDEV })\end{array}$ & P Values \\
\hline $\begin{array}{l}\text { Distribution Capability -> Attitude towards } \\
\text { Exporting -> Durian Product Exporting }\end{array}$ & 0.333 & 0.335 & 0.049 & 6.768 & 0 \\
$\begin{array}{l}\text { Promotion Capability -> Motivation to } \\
\text { Export -> Durian Product Exporting }\end{array}$ & 0.126 & 0.132 & 0.067 & 1.885 & 0.06 \\
\hline
\end{tabular}

PC: Product capability, PRC: Promotion capability, DC: Distribution capability, AE: Attitude towards exporting, ME: Motivation to export, DPE: Durian product exporting

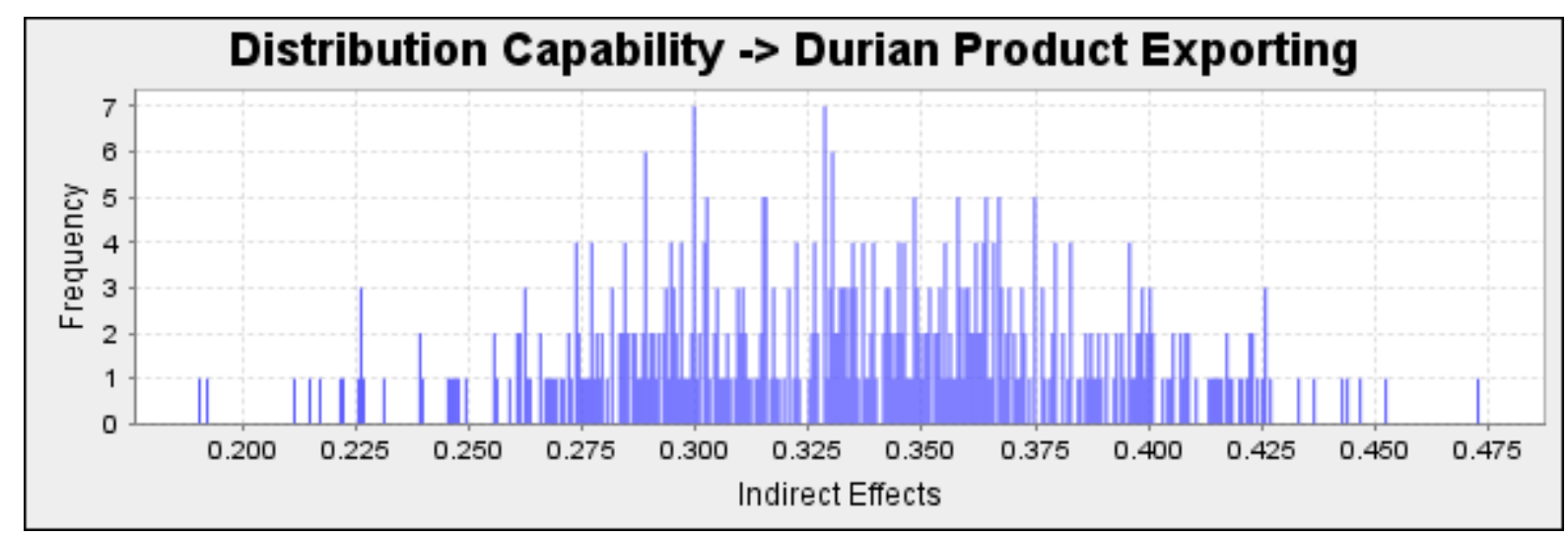

Figure 5. Indirect effect histogram: Distribution capability -> Attitude towards exporting $\rightarrow>$ Durian product exporting 
Figure 3 of the measurement model also showed the value of $r$ square and its value is 0.708 . Which means that according to Chin (1998) $70.8 \%$ change in exporting of durian product is due to determinants of marketing performance.

\section{Discussion}

This present research directed to find out the link between the impact of determinants of marketing performance on exporting durian products with the mediation of attitude towards motivation and motivation towards exporting. Participants of this study were employees working in exporting companies in the south of Thailand. Data is collected from the employees of exporting companies operated in the south of Thailand. Data is cross-sectional and the study is quantitative. The Snowball sampling technique was used and data is collected by a questionnaire via a drop-down survey method. After it, Smart PLS applied.

The results of this study revealed that determinants of marketing performance have a positive significant impact on exporting durian product. Product quality is a major variable in marketing performance. Product quality and capability to export increase, it resulted in an increase in export. Promotion of exporting product increase in host country also increase the export of durian product (Rahman, Rodríguez-Serrano, \& Lambkin, 2017). Increase in timely and effective distribution of exported product also increase the export of durian product in the south of Thailand.

Other variables those acting as the mediation are attitude towards exporting and motivation to export. From these two, the motivation to export has no effect on the exporting of durian product. And also show no mediation between promotion capabilities and exporting of durian product. Attitude towards exporting has a positive significant impact on exporting durian product. And also showed the mediation between distribution capabilities and exporting of durian product among exporting companies that operated in the south of Thailand (Martínez-Román \& Romero, 2017).

\section{Conclusion}

This study directed to find the impact of determinates of marketing performance like (promotion capabilities, product capabilities, and distribution capabilities) on durian product exporting with the mediation of motivation to export and attitude toward exporting. Data of this study collected via a questionnaire through the dropdown method from the employees working in the exporting industry of the south of Thailand. After it, Smart PLS is applied to the collected data for analyzing the data.

Results from this study revealed that determinates of marketing performance like Promotion capabilities, product capabilities, and distribution capabilities have a significant positive impact on durian export. Other variables like attitude towards exporting also have a positive significant impact on the export of durian product. Attitude towards exporting also mediates the relation between distribution capabilities and durian product exporting. Motivation to export has no significant impact on durian product innovation and also no mediation between promotion capabilities and durian product innovation among employees working in exporting companies of south Thailand. This study gives recommendations to exporters that they could focus on the determinants of marketing performance.

\section{Implications}

This study has theoretically implication that this study is a significant addition in previous literature. Purpose of this study directed to find the impact of determinates of marketing performance like (promotion capabilities, product capabilities, and distribution capabilities) on durian product exporting with the mediation of motivation to export and attitude toward exporting among employees working in exporting companies of south of Thailand.

Practically, this study has implications by giving the recommendation to exporter or policy makes of exporting companies working in the south of Thailand. For increasing the export of durian products to other countries like the Republic of China, Hong Kong, Indonesia, and Taiwan by focusing on the determinants of marketing performance. An increase in the promotion capabilities of the exported product in other countries increases export. It also revealed from studies that increase in efficient and timely distribution of exporting product to host country increase export. The main thing that effect export is the quality of durian product. The exporters should give focus on the quality of durian product that export to other countries and produce in the south of Thailand.

\section{References}

Albassami, A. M., Hameed, W. U., Naveed, R. T., \& Moshfegyan, M. (2019). Does Knowledge Management Expedite SMEs Performance through Organizational Innovation? An Empirical Evidence from Small and Medium-sized enterprises (SMEs). Pacific Business Review International, 12(1), 11-22. 
Alrubaiee, L. S., Aladwan, S., Joma, M. H. A., Idris, W. M., \& Khater, S. (2017). Relationship between corporate social responsibility and marketing performance: The mediating effect of customer value and corporate image. International Business Research, 10(2), 104-123.

Bai, L., Jiang, T., Li, F., Chen, H., \& Li, X. (2018). Distributed energy storage planning in soft open point based active distribution networks incorporating network reconfiguration and DG reactive power capability. Applied Energy, 210, 1082-1091.

Bassiri-Jahromi, S. (2018). Punica granatum (Pomegranate) activity in health promotion and cancer prevention. Oncology Reviews, 12(1).

Biswas, J. K., Mondal, M., Rinklebe, J., Sarkar, S. K., Chaudhuri, P., Rai, M., . . Rizwan, M. (2017). Multi-metal resistance and plant growth promotion potential of a wastewater bacterium Pseudomonas aeruginosa and its synergistic benefits. Environmental Geochemistry and Health, 39(6), 1583-1593.

Camilleri, M. A., \& Camilleri, A. (2017). The technology acceptance of mobile applications in education. Paper presented at the 13th International Conference on Mobile Learning (Budapest, April 10th). Proceedings, pp., International Association for Development of the Information Society.

Chin, W. W. (1998). The partial least squares approach to structural equation modeling. Modern Methods for Business Research, 295(2), 295-336.

Comrey, A., \& Lee, H. (1992). A First Course in Factor Analysis (2nd ed.). Lawrence Earlbaum Associates. Publishers: Hillsdale, New Jersey.

DeCesare, A. (2018). Working Toward Transpositional Objectivity: The Promotion of Democratic Capability for an Age of Post-Truth Politics. The Good Society, 26(2-3), 218-233.

Fan, H., Hossain, M. I., Islam, M. A., \& Yahia, Y. E. (2019). The impact of trade, technology and growth on environmental deterioration of China and India. Asian Economic and Financial Review, 9(1), 1-29.

Girangwa, K. G., Rono, L., \& Mose, J. (2020). The influence of enterprise risk management practices on organizational performance: Evidence from Kenyan State corporations. Journal of Accounting, Business and Finance Research, 8(1), 11-20.

Göral, R. (2020). Prioritizing the factors which affect the selection of hotels by consumers traveling for vacation with analytical hierarchy process (AHP) method. Journal of Tourism Management Research, 7(1), 11-31.

Gu, S., \& Prah, G. J. (2020). The effect of international financial reporting standards on the association between foreign direct investment and economic growth: Evidence from selected countries in Africa. Journal of Accounting, Business and Finance Research, 8(1), 21-29.

Guo, B., Zhao, J., Fan, X., Zhang, W., Li, S., Yang, Z., . . Zhang, W. (2017). Aluminum and fluorine co-doping for promotion of stability and safety of lithium-rich layered cathode material. Electrochimica Acta, 236, 171-179.

Hair, J., Hollingsworth, C. L., Randolph, A. B., \& Chong, A. Y. L. (2017). An updated and expanded assessment of PLS-SEM in information systems research. Industrial Management \& Data Systems, 117(3), 442-458.

Handika, R., \& Ekananda, M. (2019). Benefits and consequences of diversification: Evidence from financialzed commodity portfolios. Asian Business Research Journal, 4(1), 17-28.

Hanfan, A., \& Setiawan, A. I. (2018). Exploiting regio-centric product advantage to increase small and medium enterprises'(SMEs) marketing performance.

He, S. (2019). In Search of determinants of FDI forward spillovers: A meta-analysis. Humanities and Social Sciences Letters, 7(1), 10-19.

Ho, W. K., Ng, S. L., Vivi, N. M. S., Ng, F. S., \& Susela, D. K. S. (2020). Corporate characteristics and ESG disclosures in Malaysian public-listed companies. Humanities and Social Sciences Letters, 8(1), 91-109.

Hur, H. J., Lee, H. K., \& Choo, H. J. (2017). Understanding usage intention in innovative mobile app service: Comparison between millennial and mature consumers. Computers in Human Behavior, 73, 353-361.

Jiang, Y., Yang, S., Li, P., Luo, X., Li, Z., Hao, Y., \& Yu, P. (2017). The promotion of the transformation of quiescent gastric cancer stem cells by IL-17 and the underlying mechanisms. Oncogene, 36(9), 1256-1264.

Karahoca, A., Karahoca, D., \& Aksöz, M. (2018). Examining intention to adopt to internet of things in healthcare technology products. Kybernetes. 
Kim, M., Kim, S., Song, D., Oh, S., Chang, K. J., \& Cho, E. (2018). Promotion of electrochemical oxygen evolution reaction by chemical coupling of cobalt to molybdenum carbide. Applied Catalysis B: Environmental, 227, 340-348.

Lau, J. K. Y., \& Bruno, J. P. (2018). Location and contextual-based mobile application promotion and delivery: Google Patents.

Li, B., He, J., Li, Y., \& Li, R. (2018). A novel solid-state circuit breaker with self-adapt fault current limiting capability for LVDC distribution network. IEEE Transactions on Power Electronics, 34(4), 3516-3529.

Martínez-Román, J. A., \& Romero, I. (2017). Determinants of innovativeness in SMEs: disentangling core innovation and technology adoption capabilities. Review of Managerial Science, 11(3), 543-569.

Naureen, Z., Rehman, N. U., Hussain, H., Hussain, J., Gilani, S. A., Al Housni, S. K., . . Abbas, G. (2017). Exploring the potentials of Lysinibacillus sphaericus ZA9 for plant growth promotion and biocontrol activities against phytopathogenic fungi. Frontiers in Microbiology, 8, 1477.

Naveed, R. T., Hameed, W. U., Albassami, A. M., \& Moshfegyan, M. (2019). Online Tax System (OTS) in Pakistan: The role of Tax Service Quality (TSQ) and Information Communication Technology (ICT). Pacific Business Review International, 11(12), 78-86.

Obeng, A. Y., \& Mkhize, P. L. (2017). An exploratory analysis of employees and customers' responses in determining the technological innovativeness of banks. The Electronic Journal of Information Systems in Developing Countries, 80(1), 1-23.

Papadas, K.-K., Avlonitis, G. J., \& Carrigan, M. (2017). Green marketing orientation: Conceptualization, scale development and validation. Journal of Business Research, 80, 236-246.

Rahman, M., Rodríguez-Serrano, M. Á., \& Lambkin, M. (2017). Corporate social responsibility and marketing performance: The moderating role of advertising intensity. Journal of Advertising Research, 57(4), 368-378.

Rodrigues, R., Zhang, Y., Jiang, T., Aeloiza, E., \& Cairoli, P. (2018). Surge current capability of SiC MOSFETs in AC distribution systems. Paper presented at the 2018 IEEE 6th Workshop on Wide Bandgap Power Devices and Applications (WiPDA).

Seppälä, T., Hankonen, N., Korkiakangas, E., Ruusuvuori, J., \& Laitinen, J. (2018). National policies for the promotion of physical activity and healthy nutrition in the workplace context: a behaviour change wheel guided content analysis of policy papers in Finland. BMC Public Health, 18(1), 87.

Sheng, H., \& Wang, X. (2018). Applying polynomial chaos expansion to assess probabilistic available delivery capability for distribution networks with renewables. IEEE Transactions on Power Systems, 33(6), 6726-6735.

Wang, G., Zhang, Q., Li, H., McLellan, B. C., Chen, S., Li, Y., \& Tian, Y. (2017). Study on the promotion impact of demand response on distributed PV penetration by using non-cooperative game theoretical analysis. Applied Energy, 185, 1869-1878.

Zhao, S., \& Priporas, C.-V. (2017). Information technology and marketing performance within international market-entry alliances. International Marketing Review.

\section{Copyrights}

Copyright for this article is retained by the author(s), with first publication rights granted to the journal.

This is an open-access article distributed under the terms and conditions of the Creative Commons Attribution license (http://creativecommons.org/licenses/by/4.0/). 